\title{
The Growing Similarity Among Financial Institutions
}

\author{
JEAN M. LOVATI
}

D EPOSITORY financial institutions are able to exist because of certain efficiencies which allow them to provide credit to borrowers at lower rates and higher net returns to depositors than would be available without such intermediaries. ${ }^{1}$ These efficiencies, combined with nationally mandated priorities concerning the roles of these institutions in society, have produced institutions which are specialized in scope. Despite some efforts to maintain this specialization, financial institutions are forming a new framework within which to operate. By creating and reacting to competitive challenges, financial institutions are breaking away from their specialized roles and successfully altering traditional distinctions.

\section{CHANGES IN ASSET COMPETITION}

\section{Response of Thrifts to Rising Interest Rates}

Most depository financial institutions are subject to regulatory ceilings on the rates they are allowed to offer to attract funds. In general, these ceilings pose few problems to the institutions as long as the ceiling rates remain competitive with market rates. However, during periods of rising interest rates, short-term money market rates rise above the interest rate ceilings imposed on these institutions.

Because of their more diverse and more stable source of funds, commercial banks are not as seriously affected as "thrifts" by such an imbalance in relative interest rates;" being very specialized institutions, thrifts suffer more acutely from deposit outflows, called disintermediation, as market rates rise. When other short-term interest rates become more attractive than those which can be earned at the thrifts, depositors transfer their funds out of savings accounts and into other instruments. Twice during the last eight years, once in the second half of 1969 and again in

1This atticle focuses only on commercial banks, savings and loan associations, mutual savings banks, and credit unions.

"Thrifts laere include raving and loan associations and mutual savings banks.
1974, disintermediation put severe financial strain on the operations of thrifts.

To complicate matters, thrifts further suffer from problems relating to short-term financing of long-term assets (mortgages). Since only a fraction of thrifts" mortgage portfolios are replaced in any one year, the average return on mortgages (the major earning asset of the institutions) typically does not rise fast enough to match increases in short-term rates. At such times, thrifts are caught in an earnings squeeze.

As these situations arise, thrift institutions increasingly are being pressured to stabilize their deposit sources of funds. Thrifts, taking advantage of the current level of technology, are attempting this stabilization by offering new deposit services (which are discussed in a following section).

At the same time, when high and variable interest rates have forced many institutions to examine the structure of their assets, thrifts are emphasizing shorter-term assets in their portfolios.

Such assets typically have shorter maturities than mortgages, yet still are within regulatory bounds. Investments, such as U.S. Government and agency securities and state and local government securities, are growing in importance. Investment securities at savings and loan associations (S\&Ls) rose $\$ 23$ billion between 1970 and 1976 , or at an 18 percent annual rate, compared to an 11 percent rate between 1960 and 1970 (Table I). These securities increased to 9 percent of assets in 1976 from 7 percent in 1970 . Investment in corporate and other securities by mutual savings banks (MSBs) increased at a 17 percent rate over the six-year period, compared to a 10 percent rate in the $1960-70$ period, and rose from 16 to 25 percent of total assets between 1970 and 1976 .

To shorten the average maturity of other assets, some thrifts are emphasizing the development of consumer loans, often forging new regulatory powers. Mutual savings banks and state-chartered S\&Ls in Connecticut, Maine, and New York state have been authorized to expand the type of consumer loans they 


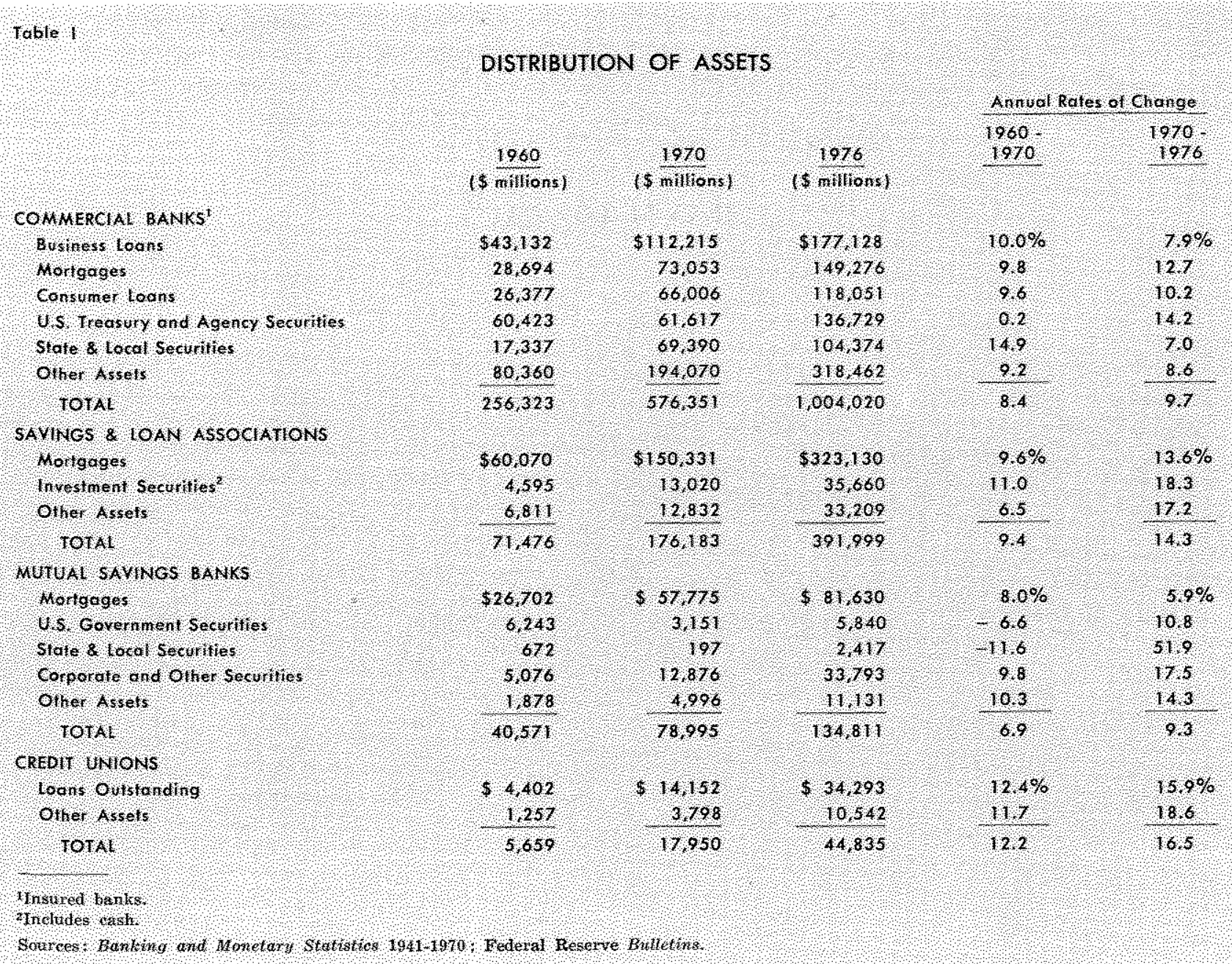

make, which includes overdraft checking. Credit card services also have been accorded increased importance by thrifts. In 1974, Visa U.S.A. Inc. altered its bylaws to permit membership for MSBs, and in May 1976, membership was extended to S\&Ls. As of August 1977,124 of the nation's 469 savings banks were offering bank credit card services. ${ }^{3}$

One of the most publicized changes in thrifts' asset structure is the variable rate home mortgage (VRM), which is being successfully marketed by some statechartered S\&Ls in California and the Midwest. ${ }^{4}$ The interest rate on a variable rate mortgage is tied to a cost of funds index such that the mortgage rate adjusts, within certain bounds, to changes in short-

${ }^{3}$ Savings Bank Journal (August 1977), p. 40.

4 In 1976, five California S\&Ls together made about $\$ 6.4$ billion in new mortgage loans. Of this amount, $\$ 4$ billion, or 63 percent, were VRMs. These five associations represent approximately 30 percent of the S\&L industry in Califonia. American Banker, May 23, 1977. term market rates. With variable rate mortgages, the returns to the thrifts on their mortgage portfolios adjust more rapidly to changes in the level of interest rates than with traditional mortgages.

\section{Increased Competition from Credit Unions}

In addition to pressures from high and variable interest rates, thrift institutions will be faced with increased competition for mortgages from credit unions (CUs). In the past, length of loan maturity at credit unions was restricted to not more than 10 years, effectively excluding CUs from the mortgage market. Although state laws often permitted more latitude to credit unions with respect to real estate loans, mortgage holdings of state-chartered CUs typically have been small.

This is likely to change as a result of legislation recently passed by Congress which enables CUs to supply mortgage loans within expanded size and maturity ranges. As a result of legislation which was 
Table II

\begin{tabular}{|c|c|c|c|c|c|c|c|c|c|}
\hline & & W avro $1 \mathrm{~s}$ & PANS & OIHE & CONSUMER & GoODS & & SOMAL lo. & ANs \\
\hline & $\begin{array}{l}\text { Gredils } \\
\text { Unions? }\end{array}$ & Commercol & $\begin{array}{l}\text { Auto } \\
\text { rononce }\end{array}$ & $\begin{array}{l}\text { federal } \\
\text { Gredit } \\
\text { Unioas? }\end{array}$ & $\begin{array}{l}\text { Commercial } \\
\text { Bonks }\end{array}$ & $\begin{array}{l}\text { Consunet } \\
\text { Cononce } \\
\text { Conponies }\end{array}$ & $\begin{array}{l}\text { recoral } \\
\text { Geodr, } \\
\text { Unions }\end{array}$ & Conneriol & $\begin{array}{l}\text { Consomer } \\
\text { Cononce }\end{array}$ \\
\hline $973 \%$ & & & & & & & & & \\
\hline January & $980 \%$ & $1001 \%$ & $1109 \%$ & $11,36 \%$ & $12.6 \% \%$ & $1904 \%$ & $113 \% \%$ & $126 \% \%$ & $2100 \%$ \\
\hline February & 998 & 10.05 & 1186 & 1137 & 12.51 & & 1140 & 1276 & \\
\hline $\mathrm{march}$ & 990 & 1004 & 1185 & 1133 & 12,40 & 18.92 & 114 & 12,11 & 20.79 \\
\hline April & 989 & 1004 & 1180 & 1130 & 1250 & & 1143 & 1274 & \\
\hline Moy & 900 & 10,05 & 1191 & 1124 & 1246 & 18.88 & 1141 & 1278 & 20.76 \\
\hline Une & 1002 & 1008 & 1194 & 1126 & 12,5 & & 1144 & 12,8 & \\
\hline Solt? & 10,12 & 1010 & 1202 & 14,7 & 12.51 & 1803 & 1144 & 1275 & 2055 \\
\hline 40 gust & 1006 & 10.25 & 12,13 & 1126 & 12,66 & & 1151 & 12,84 & \\
\hline Seplember & 909 & 10,44 & 12.28 & 127 & 12,67 & 18,69 & 1149 & 12,96 & 20,52 \\
\hline $\mathrm{Ochoser}$ & 997 & 10.53 & 12,3 & 1132 & 12,80 & & 11,48 & 13.02 & \\
\hline Hovenber & 1002 & 1049 & 12,40 & 11,4 & 12,5 & 18.77 & 11,43 & 1271 & 20.65 \\
\hline Decenber & 10,2 & 1049 & 12,42 & 11,43 & 12,06 & & 11,30 & 1312 & \\
\hline 1974 ? & & & & & & & & & \\
\hline January & 10.20 & 10.55 & 17,39 & 1141 & 1278 & 18.90 & 1137 & 12.06 & 20.68 \\
\hline February & 1027 & 10,53 & 12,33 & 11,38 & 1282 & ४ & 11,34 & 13,02 & \\
\hline Mardt & 1006 & 1050 & 12,9 & 1,23 & 12,82 & 1869 & 1116 & 13.04 & 20,57 \\
\hline $\mathrm{ApNI}$ & 1000 & 10,51 & 12,20 & 1131 & 12,81 & & 11,5 & 13,00 & \\
\hline nay & 1017 & 1063 & 12,36 & 11,31 & 12,08 & 18.90 & 1123 & 1310 & 20.57 \\
\hline Une & 10.23 & 10.81 & 12.50 & 11,40 & 13.01 & & 1131 & 13,20 & \\
\hline luly & 1031 & $10 \% 4$ & 1258 & 1139 & 1314 & 1924 & 1128 & 1342 & 2078 \\
\hline August & 10,9 & 11,5 & 12,67 & 1125 & 1311 & & 1123 & 13,4 & \\
\hline Seplenber & 1939 & 1131 & 12,84 & 1426 & 1320 & 10,30 & 1129 & 13,1 & 20.93 \\
\hline Oclobor & 10,4 & 1153 & 1207 & 1124 & 1326 & & 1144 & 13,60 & \\
\hline november & 1045 & 1457 & 1306 & 1139 & 13,16 & $19+8$ & 1160 & 1347 & 21,1 \\
\hline Decenber & 1004 & 11.62 & 13,10 & 11,6 & 13.27 & 10 & 1150 & 13.60 & \\
\hline 1075 & & & & & & & & & \\
\hline lamerory & 10.29 & 11.61 & 13.08 & 1151 & 13.20 & 19.80 & 1152 & 13.60 & 2109 \\
\hline February & 1045 & 11,51 & 1307 & 11,5 & 1320 & & 1148 & 13,4 & ß’ \\
\hline $\mathrm{katch}$ & 10,48 & 1146 & 1307 & 1148 & 13.07 & 20.00 & 1150 & 1340 & 20,80 \\
\hline spri & 1066 & 11.44 & 1307 & 1160 & 13,2 & & 1152 & 13,5 & \\
\hline Moy & 1077 & 1139 & 13,09 & 160 & 13,11 & 1963 & 1157 & 1341 & 2072 \\
\hline une & 1006 & 1126 & 1312 & 1163 & 1310 & & 11,5 & 1340 & \\
\hline moly & 1071 & 1130 & 1309 & 1156 & 1313 & 1987 & 1150 & 13,49 & 2097 \\
\hline August: & 1059 & 11,31 & 1310 & 1152 & 1305 & & 1155 & 13,37 & \\
\hline September & 10.51 & 11.33 & 13,18 & 11,52 & 13.06 & 1969 & 11,55 & 13.41 & 21,14 \\
\hline Oclober & 10,62 & 1124 & 1315 & 1164 & 1300 & & 1168 & 13,38 & \\
\hline Norember & 1058 & 1,24 & 13,1 & 1165 & 1296 & 1966 & 1164 & 13,40 & 2100 \\
\hline Decenber & 1061 & 1125 & 13,19 & 1171 & 1311 & & 11,61 & 13,46 & \\
\hline $1976 \mathrm{ß}$ & & & ॥ & & & & & & \\
\hline Jonoary & 1068 & 11.21 & 13,18 & 1168 & 13,14 & & 1159 & 13.40 & \\
\hline February & 1081 & 118 & 13,4 & 1165 & 13,02 & 1958 & 1159 & 1324 & 21,13 \\
\hline Morch & 10.73 & 11,13 & 1313 & 1161 & 13.02 & & 1156 & $13: 3$ & \\
\hline$A_{p h}$ & 1061 & 1108 & 13,13 & 1150 & 12,95 & & 1148 & 13,16 & \\
\hline MoY & 10.59 & 1100 & 1315 & 1161 & 12,96 & 1937 & 1146 & 13,27 & 20,93 \\
\hline lone & 10,65 & 1102 & 1317 & 1159 & 1299 & & 1150 & 1332 & \\
\hline Joly & 1068 & 1106 & 1316 & 1160 & 1302 & & 11,5 & 1338 & \\
\hline kugust & 1068 & 1107 & 1318 & 1156 & 1302 . & 1951 & 1150 & 13,31 & $20 \mathrm{Bg}$ \\
\hline Septenber & 10,73 & 1107 & 1321 & 1152 & 1308 & & 1142 & 13,40 & \\
\hline Oclober & 10,87 & 1104 & 13,20 & 11,51 & 1303 & & 11,4 & 13,26 & \\
\hline November & 10.87 & 1102 & 13,22 & 11.55 & 1306 & $19.5 \%$ & 1144 & 13,40 & 2123 \\
\hline Decenber & 10,86 & 1102 & 13,21 & 11,61 & 1297 & & 11,52 & 13.31 & \\
\hline
\end{tabular}

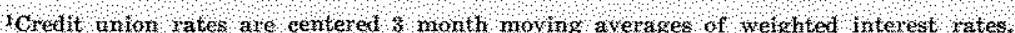

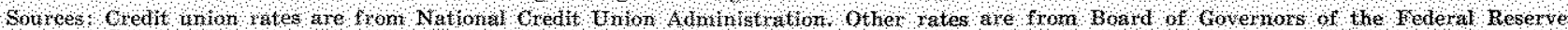
System 
formally passed in April 1977, CUs are able to make mortgages with maturities up to 30 years and home improvement or mobile home loans with maturities up to 15 years.

\section{Consumer Loan Market}

While credit unions are recent competitive additions to the mortgage market, they are mature and effective competitors with commercial banks in the consumer loan market. ${ }^{5}$ Credit unions, with $\$ 34$ billion in consumer loans in 1976, represent the third largest consumer instalment lender in the country and hold over 16 percent of the 1976 dollar volume of consumer instalment loans outstanding. Over 76 percent of credit union assets is devoted to consumer loans. Commercial banks, with $\$ 118$ billion devoted to consumer loans, hold 48 percent of the total outstanding consumer instalment debt.

From 1960 to 1970 , consumer loans at CUs increased strongly at a 12 percent annual rate. Since 1970 , growth has been even more rapid; CU loans have more than doubled between 1970 and 1976, increasing at an average annual rate of 16 percent. The consumer loan business at commercial banks has not grown as fast. Between 1960 and 1970, these loans grew at an annual rate of 9.6 percent, slightly slower, on average, than in the subseqnent six years.

The growth of CU loans, and therefore their assets, has been aided by favorable loan rates compared to those of commercial banks and other lending institutions (See Table II). Credit unions are able to profitably offer lower instalment loan rates because they experience lower fixed costs on loans. Several factors contribute to lower fixed costs, including lower costs in assembling information on loan applicants and collecting payments. Regulations governing CUs require a common bond among members before organization of a credit union is permitted. This common bond often provides an established source of information on members and facilitates the payment of the loan through payroll deductions, for example. Moreover, because of the subsidies granted them, credit unions often realize free office space and clerical help, pay no Federal taxes and generally pay little state tax, thus escaping many expenses other institutions face. ${ }^{6}$

Commercial banks, finance companies, and credit mions comprise the three largest sources of consumer loans. As mentioned above, S\&Ls and MSBs are not yet strong competitors in this market.

Pegyy Brockschmidt, "Credit Union Growth in Perspective," Federal Reserve Bank of Kansas City Monthly Review (Febriary 1977), pp. 3-13.
During December 1974, for example, direct loans on new cars carried an interest rate of 11.62 percent at commercial banks, while at credit unions such loans carried a rate of 10.34 percent. Personal loans at commercial banks were made at an interest rate of 13.60 percent at that time; at CUs they were made at an 11.56 percent rate. ${ }^{7}$ (Table II) Since credit union rates already include such factors as the cost of credit life insurance, the basic rates would be even lower than those indicated here.

Although the difference in rates charged has not been so great since 1974, it is nevertheless noteworthy. During 1976, interest rates for new auto loans at CUs varied between 15 and 53 basis points below those at commercial banks. Personal loans at credit unions fluctuated between 157 and 198 basis points below personal loan rates at commercial banks.

As a result, credit unions are advancing their position in the consumer loan market. Based on instalment credit outstanding, CUs held 13 percent of the total credit outstanding in 1972 ( 15 percent of automobile credit). In 1976, they held about 17 percent of total credit outstanding (23 percent of automobile credit). Commercial banks, on the other hand, have held a fairly constant share of instalment credit, averaging about 48 percent of the total. The share of automobile credit held by commercial banks declined from 62 percent in 1972 to 58 percent in 1976.

Thus, CUs have found themselves in a favored position relative to commercial banks in the consumer loan market. This advantage, combined with favorable interest rates at a time when the public has become increasingly interest-rate conscious in the face of inflation, has propelled the growth of CUs. As a result, credit unions are providing commercial banks with intensifying competition for consumer loans. Moreover, as S\&Ls and MSBs continue to move to shorten the maturity of their asset portfolios, thrifts will become more effective competitors in this market as well.

Future competition in this market is likely to focus on credit card services. Membership rules of Visa U.S.A. Inc. were extended in 1976 to include credit unions. Recently, Visa approved 32 credit unions as card-issuing members, 22 of which participate in a pilot program sponsored by Credit Union National

\footnotetext{
7 Interest rates for credit unions are from the National Credit Union Administration and are centered three-month moving averages of weighted interest rates; those for commercial banks are from the Board of Governors of the Federal Rem serve System.
} 


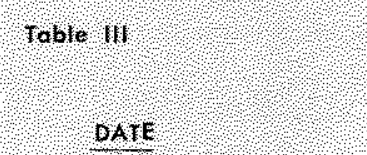

Septeniber 1970

June 1972

Septenber 1972

Jonuary 1974

lantory 1974

April 107

Noy 1974

June 1974

August 1974

Septenber 1974

December 1974

Januory 1975

April 1975

Mas 1975

June 1975

\section{SEIECTED REGULATORY AND INSTHUTIONAL CHANGES}

\section{COMMERCAI BANKS}

\section{OTHER AMANCIAL WSTHUTIONS}

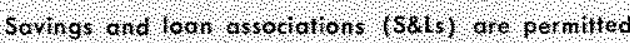
10 noke preauthoriked nonbegolloble tronsfers

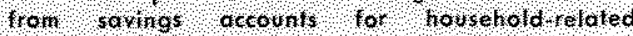
$\mathrm{epenses}$

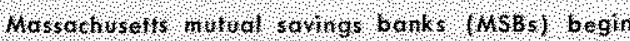

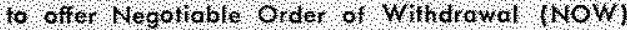
acounts

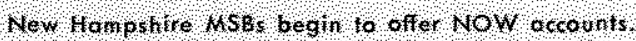

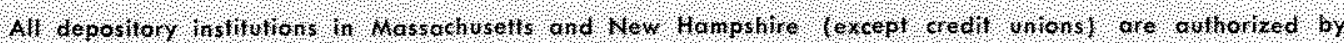

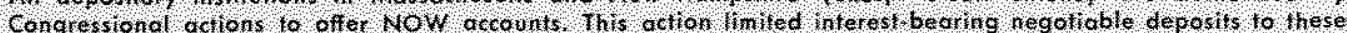

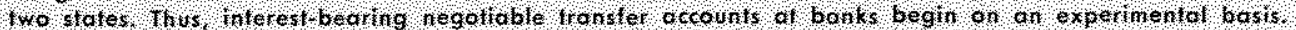

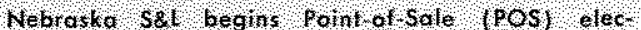

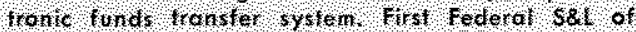

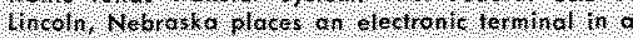

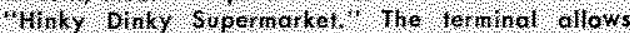

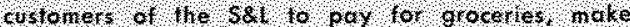

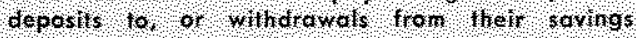
aceounts

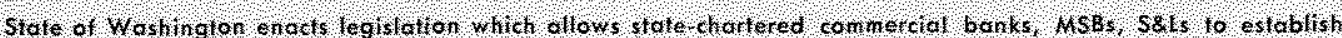

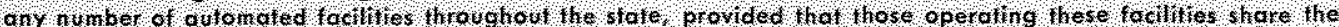

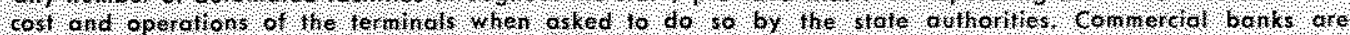

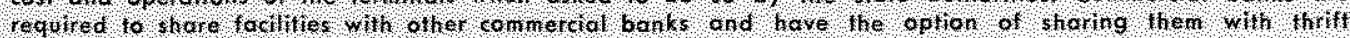

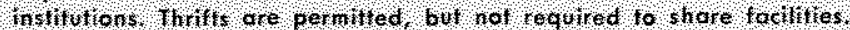

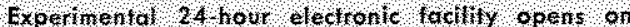

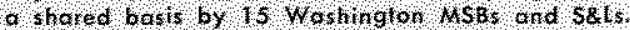

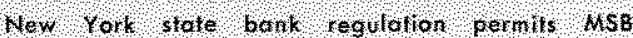

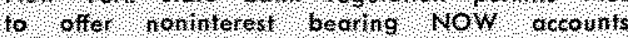
JuNows)

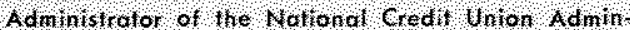

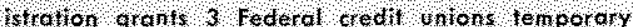
outhorly lo begh oferthg shore drofs these 3

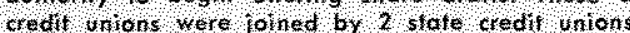

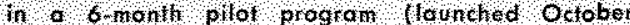

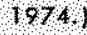

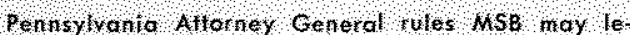
golly oller 0 lom of negolleble onder of wh drawal acrowt

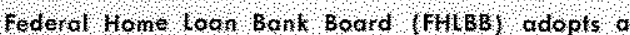
regulation which glves depos hor trovellitg thore hon 50 miles hom hel homes acess 10 heh soyngs aceount bolances 1 hough ony of her fed erallowsured $\$ \&$ by means of a Traveler Conven rence Windratrd (wire or lelephone occess)

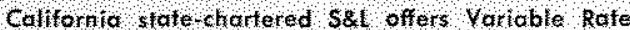
Mortgenes $(\mathrm{HM})$

Mhneseto $\mathrm{MsB}$ introduces Pay By phone service

HHBB adops two regulations

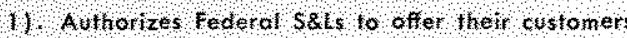
bill poying servlee from inferes lbealing sey $\mathrm{ngs}$ aroonts.

hom a customer $\$$ sorm s accown 10 o denand depost acoum upon telephohe order from the customer

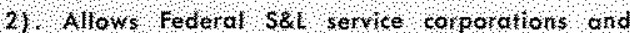
componies o moke consumer lowns llintied to states wheh ollow such odfyty and seblect to thte restrfononsl

eBCT oporoled exdustrely by a notional bank is subfected to a $50 \mathrm{mlll}$ geographied restrithon onless CBCt is orolable 10 bo bhored wh one on more depos 1 nstrutons a nathonal bark noy use $\mathrm{a} \mathrm{BCT}$ estahisthed and operoled by some on her nshtwon and moy portatpale $\mathrm{n}$ o statewide EFTS swent

Oregon governon slans hto law leglstation which ollows the nlates only $\mathrm{MSB}$ to ofer dredkn acoumts. 


\section{SELECTED REGULATORY AND INSTITUTIONAL CHANGES (CONIInUEd)}

\section{DATE}

June 31,1075

September $1 \%$

\section{october 1975}

November 1075

Decenber 1975

Janugry 1976

February 1976

May 1976

October $4: 1976$

Fobruary 14,1977

\section{COMMERCIAL BANKS}

U, S Districh Cour Judge Robinson rules CBCT outhotezed ton national banks by the Complroller of the Currency are llegal and thes be shut down. aboul $72 \mathrm{CBCT}$ owned by national bonks towe been hamalled an yomous parls of the counthy under

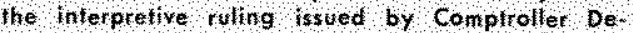
cenber 12 , 1974 , Robinson's decision diredfy at lacks 1 e Decenber 12,1974 interpretation, calling Ne terminals branches, both os def ned by the U:S Supteme Court an is 1969 Plant Clly case and as consfrued by Congress when I passed the MeFodden Al $1 \mathrm{1} 128$

Commerclal banks or outhoriato to make pro$00 t h o t$ ted nonnegol able transfers from a bus

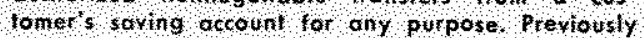
Whee 1962 , such transfers were finted to montgogesreloted poyments.

Federa deserve amends defintion of savings deposits in Regulations $\mathrm{D}$ and $\mathrm{O}$ lo permif busities sowings okcounls up $10 \quad 8150,000$, ol thenbet bakks:
Mossachuselis MSE mHoduces YRM progran.

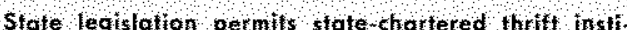
futions In Alane to ofter persond aliedking accounts

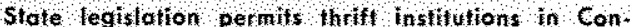
netteut to offer persondl efeeking accoumts.

White the ow thonty fo offer share dratts was still oflelally femporary addilonol cedit unlons begi to ofter shere droft accounts kollowing the end of the 6 month phot program trithated in foll 1974 .

A of one yedrend 222 dedif untons loughly 1 percenth in 44 sfoles have been approved to ofter share drats to the sh sharaholders.

Federd heserve stutem adopts a policy for duto mated cleck clearing systems (ACHs) to offer theit services on a tondiseminatory basis to all types of finonciel insfifutions

Ihnots S\&ls begin offering noninterest beoring Now accounts

Congres wathorizes all depository institufions in New England to offer inferest paylng NOW accounts (effective: Match 1, 1976 )

US Court of Appeals for the District of Columbia uptiolds eatier ruing by the U.S Disfrict Court for the Distriet of Columbia that nationat banks CBCT are branches under the McFadden Act

U.S. Supreme Court lets stand ruling that $C B C T$ are bank branches

lowa statewide electronte banking system beains operatitg and represents the notion s first shared statewide network, encompassing a broad ronge of large and small banks in lowa (Al last count the system had 33 partitpating banks 92 merehan teminals operate through o switef or centra computerl
New York governor signs legistation permitting checkng actounts, including over draft privileges, at state chartered MSBs and SaLs
All by 15 of the naton's 470 MSBs have elther Now accourifs traditional checking accounts of a combination of the two.

legislation enched to expond eredit vanon lending authorlfy including authorify to moke 30 year mortgage loons. 
Association. As $\mathrm{CU}$ s are given endorsement to apply for Visa credit, they undoubtedly will improve their competitive position. Federal credit unions are limited by regulation to charging no more than one percent per month on the unpaid balance of a loan. Under present conditions, this regulation would limit interest rates on credit eard services to 12 percent per year, while many banks typically are charging 18 percent annually.

\section{CHANGES IN LIABILITY COMPETITION}

Deposit liabilities of financial institutions are also undergoing change, primarily surrounding the distinetion between demand and savings deposits. Important institutional changes have occurred since 1970 which have allowed more vigorous competition for deposits among institutions (See Table III for a listing of some of these developments). Combined with various maximum rates of interest allowed financial institutions, these changes will likely translate into new positions in the competition for deposits (See Table IV).

Some thrifts were permitted in 1970 to make preauthorized nonnegotiable transfers from savings accounts for household-related expenditures. However, the major impetus for change occurred in 1972 when MSBs in Connecticut and New Hampshire began to offer Negotiable Order of Withdrawal (NOW) accounts. These accounts are essentially interest-bearing savings accounts on which checks can be written. While, at first, introduction of NOW accounts was limited to these two states, authorization for NOW acoounts was expanded in 1976 to include MSBs, S\&Ls, and commercial banks in all New England states (Table V). ${ }^{8}$ Moreover, expanded authority for NOW accounts is currently being proposed to include all states. ${ }^{9}$

At credit unions, similar services are called "share draft accounts." Introduced at five credit unions in 1974, share drafts are now available at more than 940 CUs in 46 states. ${ }^{10}$ These accounts, offered throngh a Credit Union National Association program, permit

\footnotetext{
rOn January 1, 1974, total NoW account balances in Massachusetts amounted to $\$ 138$ million. Three years latex, in January 1977 , NOW balances totalled $\$ 1.47$ billion. During the same time period, NOWs in New Hampshire increased from $\$ 5$ million to $\$ 180$ million.

SSome institutions, mainly state-chartered thrifts, have surpassed the initial offering of NoW accounts. Savings banks in New England and five other states are authorized to offer demand deposit accounts.

to About $200,000 \mathrm{CU}$ members wrote approximately $\$ 800$ million in share drafts during 1976.
}

payable-through drafts which are drawn on the members' interest-bearing share accounts. Share drafts are processed through the credit union's account at a commercial bank.

In addition to NOW accounts, savings and loan associations have also initiated several services which allow them to compete for denand deposit business that has gone, traditionally, to commercial banks. Primarily through the use of electronic services, these thrifts have access to another source of deposits, one which they may be able to more successfully retain than other sources during business cycle fuctuations. At the same time, these services allow thrift depositors to use their savings accounts more like the transaction accounts of demand deposits.

Through electronic terminals, called remote service units (RSUs), depositors of thrift institutions are able to perform within seconds many of the transactions formerly conducted through demand deposit accounts, such as withdrawing cash, making charge account and loan payments, and transferring funds from one account to another. ${ }^{11}$ One basic advantage of these units is that they frequently are located in such convenient places as supermarkets, airports, and factories. Moreover, S\&Ls as well as MSBs have introduced telephone transfers to third parties and automatic payment services which allow their customers to more easily utilize their savings accounts for transactions purposes. ${ }^{12}$

As far as customers are concerned, the new deposit services at nonbank institutions are little different from demand deposit accounts of commercial banks, except in one important respect: typically, nonbank deposit services explicitly pay interest, whereas those of commercial banks do not.13 Commercial banks have been prohibited since 1933 from explicitly paying interest on demand deposits. Savings deposit accounts at S\&Ls and MSBs, on the other hand, are permitted by law to bear interest which is one-quarter of one percent higher than similar accounts at commercial banks. ${ }^{14}$ Thus, not only have thrifts begun to

\footnotetext{
${ }^{11}$ Between January 1974 and December 1976, 112 applications for remote service units have been approved by the Federal Home Loan Bank Board. Federal Hone Loan Bank Board Joumal (April 1977), p. 39.

12 Fourteen savings banks in New York, Connectiout, Maine, New Jersey, Pennsylvania, and Washington offer pay-byphone services (Table VI).

to In a few areas, nonbank deposit accounts called NonInterest Negotiable Order of Withdrawal accounts, (NINOWs) do not bear interest.

" Current ceilings on passbook accounts at commercial banks and thrifts are 5 and $5^{1 / 4}$ percent, tespectively.
} 


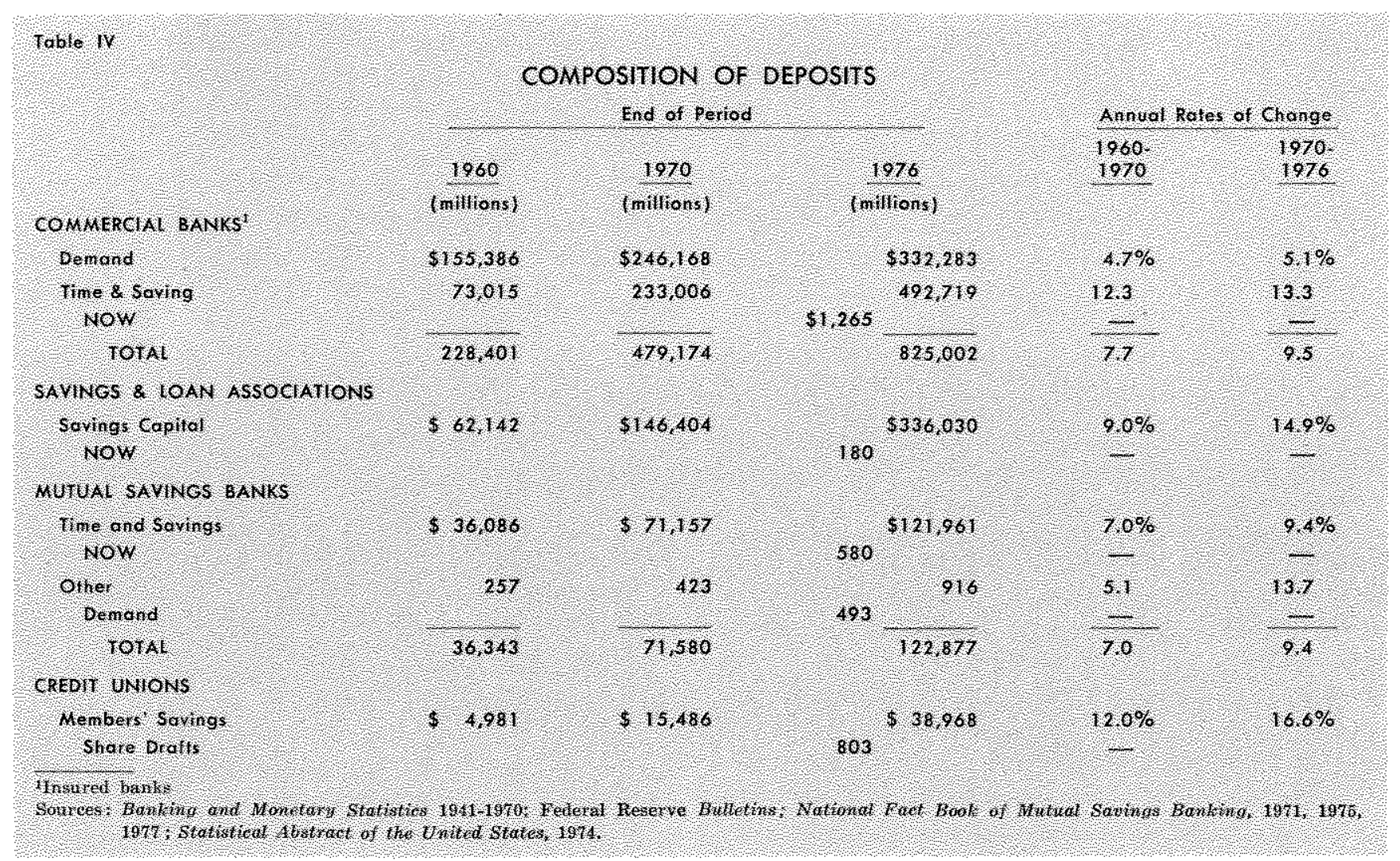

compete with commercial banks for demand deposits, but by servicing their "demand deposits" from savings accounts, thrifts generally seem to be making the most of their interest rate advantage.

Credit unions are in an even better competitive position. The maximum rate permitted members' savings accounts at CUs is 7 percent. Although not all CUs pay the highest rate, about 50 percent paid between 6 and 7 percent in 1975, significantly higher than the ceiling rates at other institutions. This favorable rate differential for CUs not only appeals to current and potential members, but also allows credit unions to retain funds when other institutions are suffering from disintermediation.

By increasing the convenience of the services which compete with demand deposits, nonbank institutions effectively have decreased the transactions cost to customers of their accounts. Coupled with the higher maximum interest rates allowed these institutions, their deposit growth rates generally have been stronger than those of commercial banks. Since 1970, savings of credit union members have increased at a 17 percent annual rate, and in the last two years, have grown at about a 19 percent rate (Table IV). Total deposits of commercial banks, on the other hand, grew at nearly a 10 percent rate in the period between 1970 and 1976 , up from the 8 percent rate which prevailed between 1960 and 1970. Savings capital of S\&Ls and deposits of MSBs grew at annual rates of 9 and 7 percent, respectively, between 1960 and 1970. The latter institutions maintained deposit growth rates of 15 and 9 percent, respectively, since 1970.

While many new demand deposit services began in 1974, data on such services tend to be incomplete, making comparisons difficult. However, NOW account data are the most complete, and available across institutions. These data indicate that the dollar volume of NOW accounts at commercial banks increased from $\$ 65$ million in 1974 to $\$ 1.3$ billion by the end of 1976. NOWs at S\&Ls and MSBs have also shown intense growth, though not as strong as at commercial banks. Between 1974 and 1976, NOWs at thrift institutions increased $\$ 146$ and $\$ 367$ million, respectively (Table $\mathrm{V}$ ). In the same two-year period, share draft balances at CUs grew from $\$ 375,000$ to $\$ 803$ million.

In an era of rising prices, people have become more aware of the cost of holding money. More money holders are seeking methods of reducing noninterestbearing claims in favor of highly liquid earning assets that can either be easily transfomed into payments 


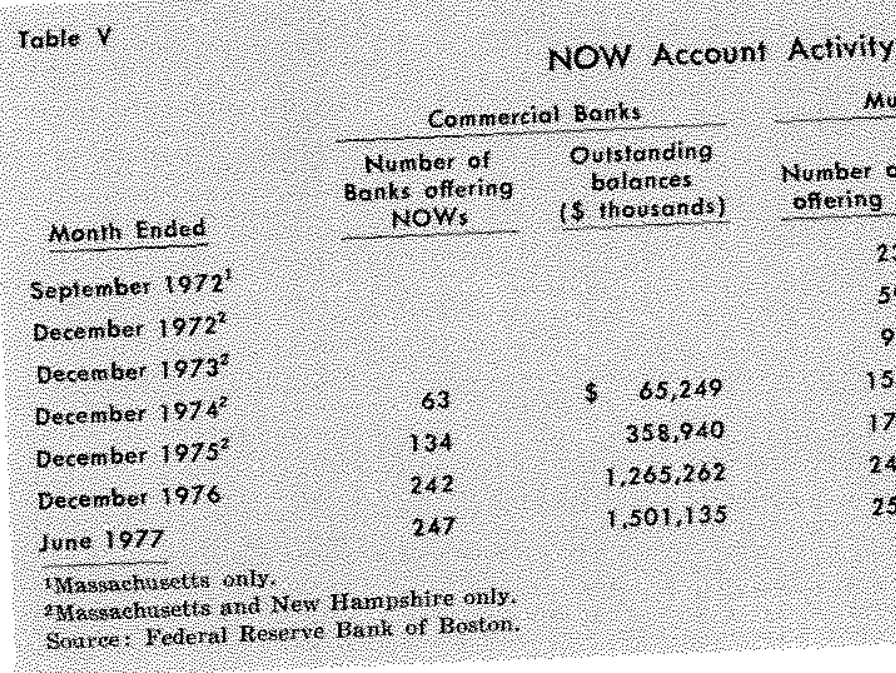

media or used indirectly for payments. The above figures tend to indicate the extent to which these preferences are influencing relative rates of deposit growth.

\section{IMPACT}

In certain areas, new competition has prompted commercial banks to retaliate in order to maintain or regain their competitive position. In some cases, commercial banks have been successful in initiating telephone transfers and automatic payment services similar to those at nonbank institutions. ${ }^{15}$ Perhaps the best example of a situation in which commercial banks have been able to equatize competition is the case of NOW accounts in New England. Initiating NOW accounts in 1974 , two years after their introduction by MSBs, commercial banks have surpassed savings banks in NOW balances and have about equalled the number of savings banks offering the accounts (Table V). ${ }^{16}$

In other cases, commercial banks have been less successful. For example, although national banks have initiated electronic terminals, called Customer Bank

15 One area in which commercial banks have been successful arual footing with S\&Ls is for Individual in attaining at equal footing with $\mathrm{Keogh}$ plans. S\&Ls offer Fetirenent Acounts (IRAs) and 7.75 percent interest rate, these aecounts to savers at a 7 comparable accounts at a while commercial banks offered comparable aty 6,1977 , commaximum rate of 7.5 percent. Efective the Federal Peserve mercial banks which are members of the federal deposit System can introduce a new category of As and Keogh aceounts which are avalable for 7.75 percent.

plans and pay a maxmintrin "Recent Developments in the NOW 16See Ralph C. Kimball, "Recent Development Donald Basch, Account Experment in New England and Donats" "Fed"The Diffusion of NOW Accounts in Massachusets, Economic eral Reserve Bank of Boston, New 1976 , pp. 3-19 and pp. Review (Novenbe

20-30, respectively.
Communication Terminals (CBCTs), placement of them has been limited and certainly more restrictive than that of the similar Remote Service Units of savings and loan associations. The courts have judged that CBCTs are branches as defined in the McFadden

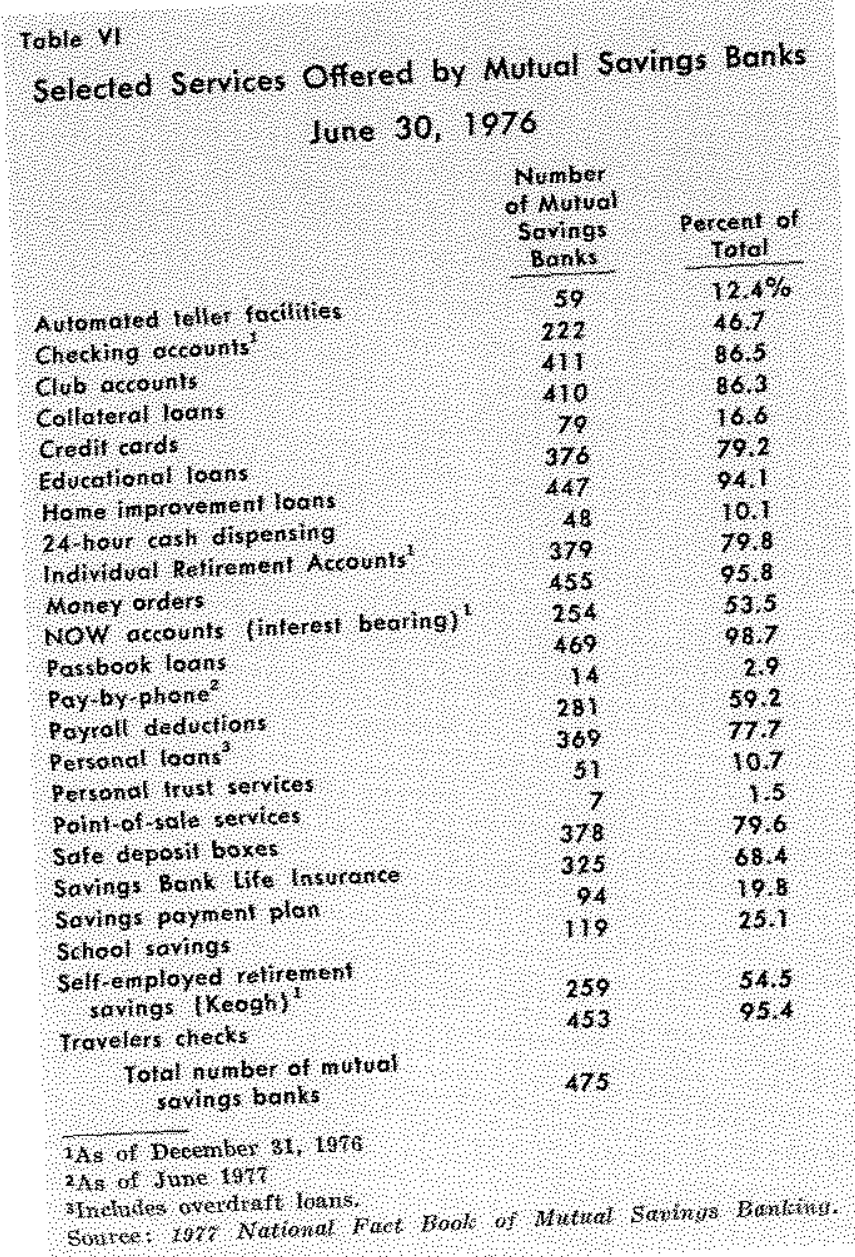


Act of 1928, a severe competitive blow to commercial banks. This ruling subjects placement of CBCTs to state laws prohibiting or limiting branch banking by commercial banks. S\&Ls are not subject to any comparable ruling.

Moreover, as more institutions pay interest on their "checking accounts," more pressure is placed on commercial banks to pay interest on comparable accounts. Legislation has been proposed which would allow all financial institutions in the nation to offer NOWs, with an identical ceiling rate. ${ }^{17}$ Legislation of this sort would eliminate the interest rate differential on passbook/NOW accounts among institutions.

With one uniform interest rate, it is a short step to complete elimination of all interest rate differentials. Moreover, if nonbank institutions have formal access to other sources of funds, regulators may argue that the institutions no longer "require" the advantage of the interest rate differential to maintain deposit flows.

Whether or not such proposals pass, the innovations which have occurred already have increased the number of alternative services available to consumers. Consumers are now able to obtain larger mortgages at CUs, a wider range of consumer services at MSBs, and closer substitutes for checking accounts at S\&Ls. Moreover, the quantity and variety of services offered at each type of financial institution will probably continue to increase in the future.

Such changes are altering the focus of most financial organizations. Having begun as basically specialized institutions, they are now taking on a more diverse character. The distinction between the asset and liability powers of bank and nonbank institutions is be-

\footnotetext{
17Credit mions have been included among such legislative packages for share drafts.
}

coming blurred, and with it, the distinction between the institutions themselves.

\section{CONCLUSION}

Commercial banks, savings and loan associations, mutual savings banks, and credit unions perform many similar functions. They accept the savings of economic units and allocate them to borrowers. Since 1970 , these institutions have been becoming similar in more specific ways. Nonbank institutions are diversifying and broadening the scope of their assets. S\&Ls are including shorter-term assets in their portfolios; MSBs and CUs are devoting more assets to various types of consumer loans. In terms of liabilities, demand deposit accounts are no longer the exclusive domain of commercial banks. All types of thrift institutions are permitted some type of demand deposit services.

Thus, competition is intensifying among the institutions and will likely provide them with incentives to increase efficiency and reduce costs to customers in the future. As a result, consumers have more alternatives for "banking" services from which to choose. In the process, asset and liability powers of the institutions have yielded to equalizing forces. Regulations and incentives for specialization, which maintained the distinction among institutions, are being broken down.

The traditional roles of nonbank financial institutions are changing; their domain, once narrow, is now much more extensive and similar to that of commercial banks. However, there is likely to be some limit to this process of financial institutions becoming more similar. Given current trends, the extent of specialization of the institutions is likely to be determined by competitive forces as well as by public policy to channel credit to specific uses.

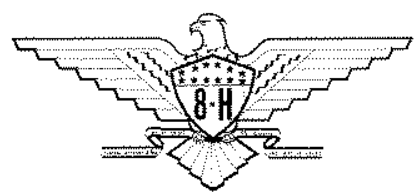

